\title{
Characteristics and development of the flexural forebulge and basal unconformity of Western Taiwan Foreland Basin
}

\author{
Ho-Shing $\mathrm{Yu}^{\mathrm{a}, *}$, Ying-Wei Chou ${ }^{\mathrm{b}}$ \\ anstitute of Oceanography, National Taiwan University, Taipei, Taiwan, ROC \\ ${ }^{\mathrm{b}}$ Chinese Petroleum Cooperation, Taipei, Taiwan, ROC
}

\begin{abstract}
The Western Taiwan Foreland Basin formed during the Early Pliocene as the flexural response to the loading of Taiwan orogen on the Eurasian plate. Using more than $4000 \mathrm{~km}$ of marine multi-channel seismic reflection profiles and 22 exploration wells offshore and on land, we recognized a major unconformity separating the overlying sediments of foreland basin from the underlying passive margin strata and a flexural forebulge located at the distal part of the foreland basin. Those allow us to refine and extend the area of the Western Taiwan Foreland Basin to the middle of the Taiwan Strait. The Western Taiwan Foreland Basin is about $350 \mathrm{~km}$ long and $150 \mathrm{~km}$ wide between the west front of the Taiwan orogen and the Chinese craton.

Seismic lines show that a narrow zone of uplifted Miocene passive margin sequences at the distal parts of the foreland basin extends approximately parallel to the strike of the deformation front of the Taiwan orogen. The Miocene bulge is generally $200 \mathrm{~m}$ high, a subtle morphologic/structural feature, and is characterized by an unconformity where Quaternary sediments overlie the eroded Miocene strata. Positive Bouguer gravity anomalies associated with the bulge on the cratonic side suggest that the Chinese continental margin is flexed upward to produce the bulge with higher density materials compared to the negative gravity anomalies of the sediments deposited in the adjacent foreland basin.

The base of the foreland basin fills is a regional angular unconformity. The stratigraphic patterns of sediments overlying the unconformity change laterally, towards the Taiwan orogen, into conformity or disconformity of insignificant gap at the coastal areas. In contrast, the chronostratigraphic gap across the unconformity increases cratonward, with the largest gap at flexural forebulge. The increase in stratigraphic gap reflects the progressively younger transgression of the Pliocene-Quaternary orogenic sediments from Taiwan onto the Chinese passive margin combined with progressively older Miocene units subcropping towards the forebulge. The characteristic geometry, stratigraphic pattern and large gap up to 10 Ma suggest that the basal unconformity is a flexural forebulge unconformity rather than a type 1 unconformity, mainly due to sea level change.

The flexural forebulge and associated basal unconformity mark transition from shelf-slope-rise deposition on a passive margin to deposition in a foreland basin associated with a convergent margin. The flexural unconformity developed during the collision between the Luzon Arc and the Chinese continental margin, reflecting the uplift and erosion of progressively cratonward migrating forebulge. (C) 2001 Elsevier Science B.V. All rights reserved.
\end{abstract}

Keywords: flexure; forebulge; unconformity; foreland Basin; Taiwan

\section{Introduction}

Flexure of foreland creates an asymmetrical subsiding basin bounded on the cratonic side by a peripheral

* Corresponding author. bulge. The flexural bulge is a subtle morphologic/ structural feature, compared to the adjacent foredeep, with a height from a few tens to a few hundreds meters (Jacobi, 1981; Stockmal et al., 1986; Crampton and Allen, 1995; DeCelles and Giles, 1996). The recognition of a peripheral forebulge and 
forebulge unconformity is important in evaluating the dynamics of foreland basin development. It has direct link to the flexural response of the continental margin to the topographic load of the thrust-belts and to the subsequent progressive sedimentation. During the early stage of underfilled foreland basin, the peripheral bulge may uplift the shelf on the cratonic side above sea level, thus subjected to subaerial erosion and resulting in an unconformity. In the late overfilled phase, the peripheral forebulge is tended to be buried by sediments shed from the orogen and may become a subdued forebulge (Stockmal et al., 1986; Crampton and Allen, 1995; DeCelles and Giles, 1996).

The distance between a forebulge and an orogenic wedge front and the height of a forebulge are direct insights into the flexural response of foreland plate. In general, high flexural rigidity creates a low and wide forebulge, whereas low flexural rigidity produces a relatively high and narrow forebulge (Flemming and Jordan, 1989; Sinclair et al., 1991). The forebulge is a key element of the foreland basin system (DeCelles and Giles, 1996). The correct identification of a peripheral forebulge on the cratonic side should provide a better constrain to define a complete foreland basin system.

The peripheral forebulge unconformity is a megasequence boundary separating the overlying foreland basin fills from the underlain passive margin sequences and differs from type 1 unconformity characterized by a major eustatic sea level fall (Crampton and Allen, 1995). The characteristic geometry of the forebulge unconformity and progressive onlap of overlying sediments are clues for understanding the history of foreland basin sedimentation associated with the events of the advancing orogen. The recognition and correct interpretation of a peripheral forebulge and associated basal unconformity should provide useful information for investigating the stratigraphic evolution of foreland basin sequences.

\section{Regional setting: the Western Taiwan Foreland Basin}

Taiwan is located at the junction between the Ryukyu and Luzon Arcs in the northwestern Pacific
(Fig. 1). The fold-thrust mountain belt in Taiwan resulted from oblique collision between the passive Chinese margin and northern Luzon Arc in Late Cenozoic (Biq, 1972, 1997; Chai, 1972; Bowin et al., 1978; Chi et al., 1981; Suppe, 1981, 1984; Ho, 1988). The geological history of Taiwan is well documented, although some details of the orogenic processes remain uncertain. However, the west flanking foreland basin has not been fully investigated until the work of Covey $(1984,1986)$. In west Taiwan the Pliocene-Quaternary foreland basin is filled with sediments up to $5000 \mathrm{~m}$ thick derived from the Taiwan orogen. The asymmetrical and wedge-shaped foreland basin was named Western Taiwan Foredeep (Covey, 1984) and can be classified as a peripheral foreland basin in the classification of Dickinson (1974).

Only few papers related to the Western Taiwan Foreland Basin have been published (Teng, 1987; Shiao and Teng, 1991; Chou et al., 1994; Chiang, 1998). Lately, using industrial marine seismic profiles and well data, Chou and Yu $(1997,1998)$ refined and extended the boundary of the Western Taiwan Foreland Basin from the coastline to the middle of the Taiwan Strait (Fig. 1). They also pointed out that a prominent flexural forebulge unconformity exists in the middle of Taiwan Strait at the most distal part of the foreland basin. However, the characteristics and development of the flexural forebulge and the basal unconformity associated with uplift and erosion of the forebulge were not fully discussed. This paper aims at describing the characteristics of the forebulge at the basin margin and the associated basal unconformity and to relate them to the development of the basin. Results of this study can be used as input for geophysical modeling to determine the flexural properties of the underlain foreland plate in the future study.

\section{Data and study area}

More than $4000 \mathrm{~km}$ of industrial migrated multichannel seismic reflection profiles and 22 exploration wells were used for this study (Fig. 2a). Most of the seismic sections were acquired and processed by Chinese Petroleum Company between 1976 and 1985. Data of nannofossil and geophysical logging 


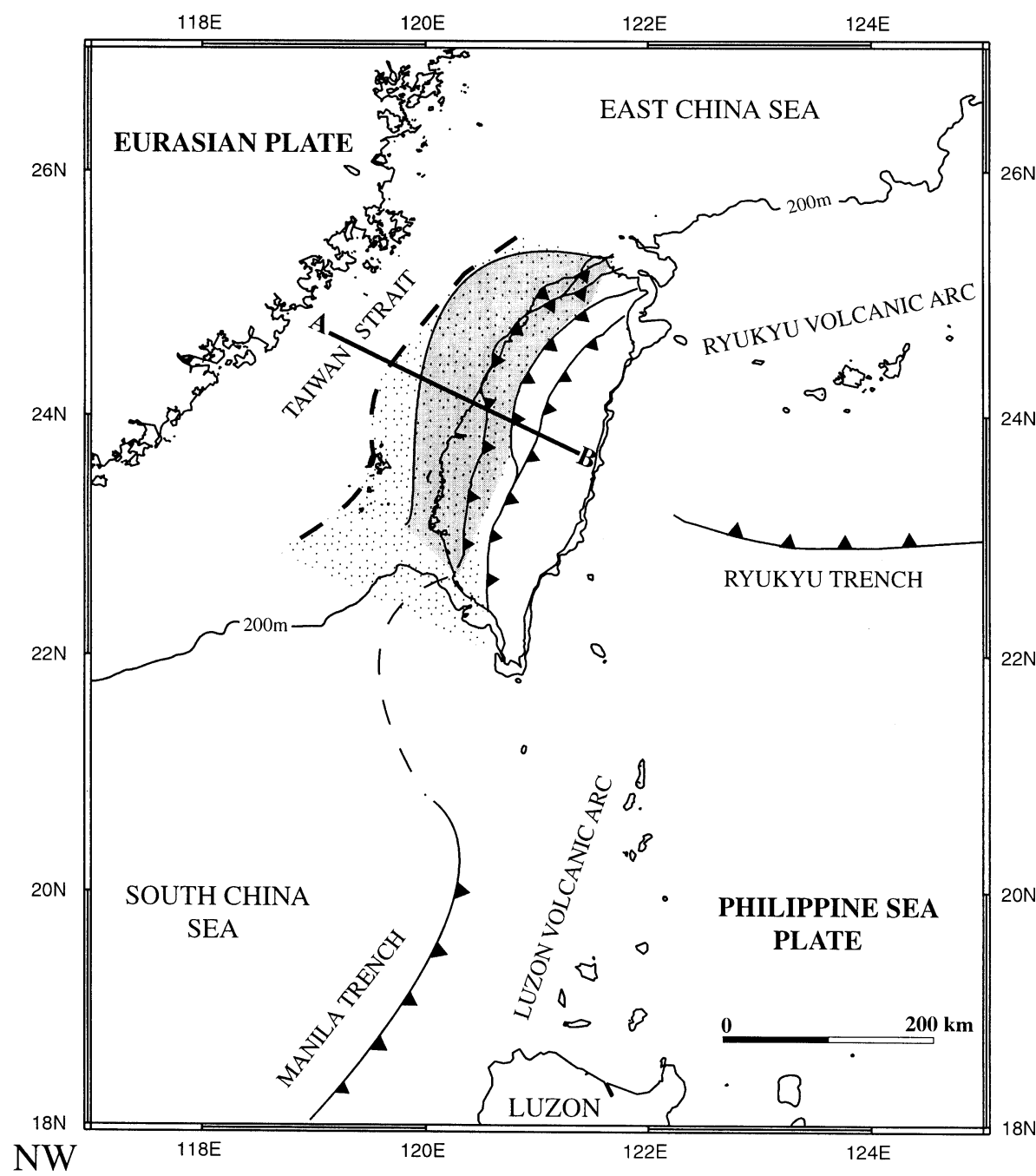

SE

A forebulge

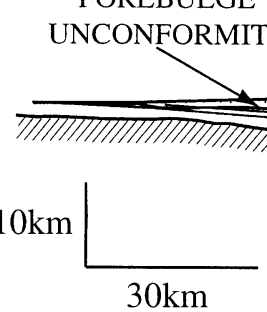

TAIWAN OROGENIC BELT

B 

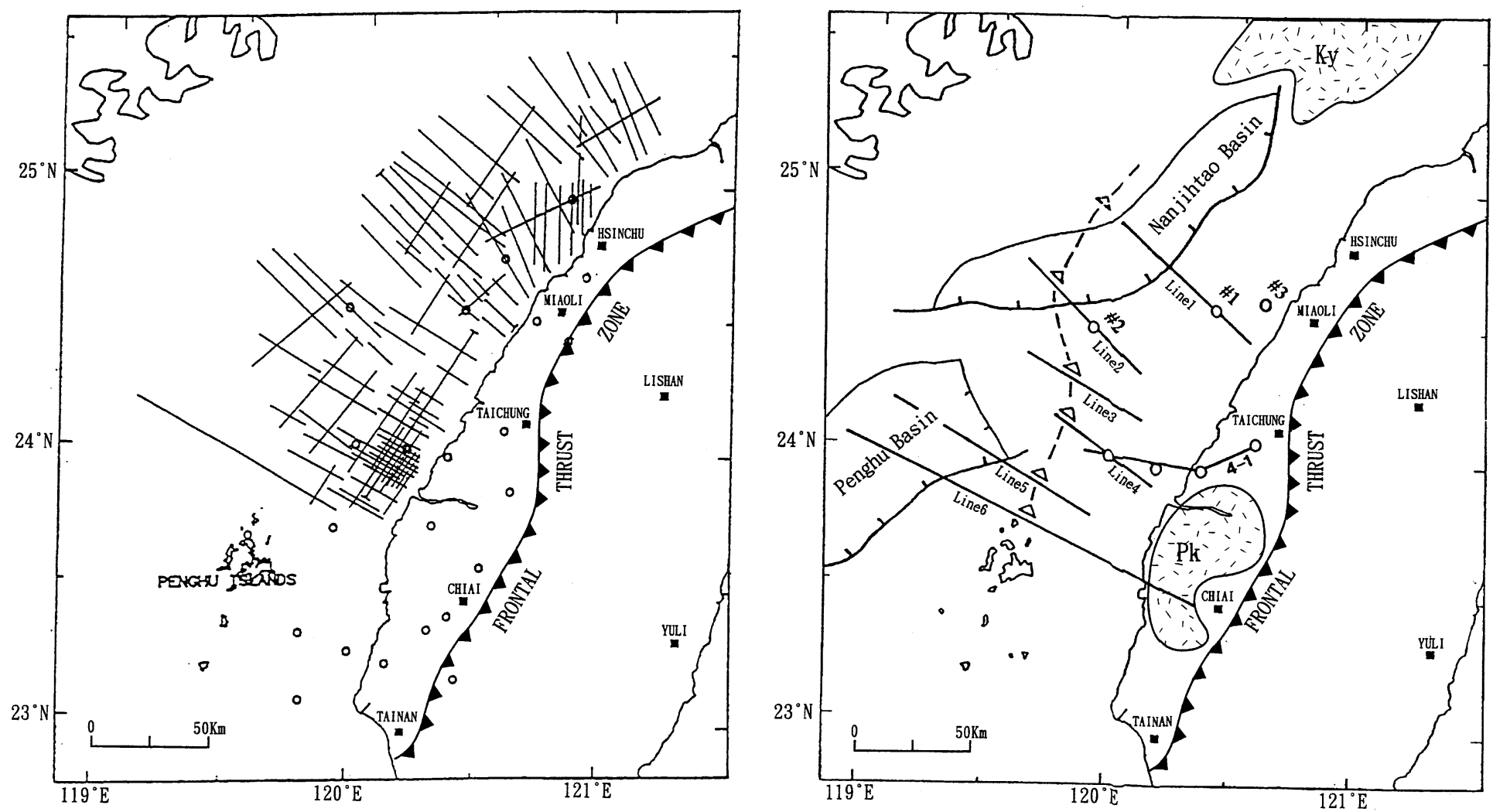

Fig. 2. Locations of marine seismic lines and exploration wells offshore and onshore for this study. The frontal thrust zone of Taiwan is marked by solid triangles (left). Geologic units around the study areas: Ky (Kuanyin basement high); Pk (Peikang basement high). Nanjihtao and Penghu basins are early Tertiary rift basins. Six selected seismic lines (e g. lines 1-6) are examined to determine the approximate locations of the flexural forebulge of the foreland basin (right). The approximate locations of the maximum relief on forebulges are marked by open triangles. 
were obtained from bore-hole information of these wells providing fairly good age calibration on seismic profiles.

Miaoli-Taichung-Tainan and adjacent offshore areas of western Taiwan are the study area where the basal unconformity separating the foreland basin deposits from the underlain passive margin sequence needs to be determined to evaluate the stratigraphic evolution of the foreland basin. The frontal thrust zone of Taiwan is close to the study area so that marine seismic sections can be correlated to the seismic profiles on land, allowing the determination of the distal and proximal stratigraphy of the foreland basin. Six seismic lines (e.g. lines 1-6) are examined to determine the approximate locations of the forebulge of the Western Taiwan Foreland Basin (Fig. 2b). The study area is geologically bordered to the north by the Kuanyin basement high, to the east by the Western Foothills, to the west by the Nanjihtao rift basin and to the south by the Peikang basement high (Fig. 2b).

\section{Evidence for flexural forebulge based on recognition of regional basal unconformity of the foreland basin}

Seismic lines (Figs. 3-5) calibrated by bore-holes show that a major basal unconformity separates the Pliocene-Quaternary foreland basin sequences from the underlying Miocene passive margin sequences. Seismic line 1 shows that Pliocene-Quaternary foreland sediments progressively onlap the Miocene sequences of passive margin of the Chinese craton (Fig. 3). The base of the Pliocene-Quaternary sediments tilts upwards and towards the Chinese margin and ends approximately at the middle of the Taiwan Strait where the Quaternary sediments unconformably overlie the Lower Miocene strata. Farther south, both seismic lines 2 (Fig. 4) and 5 (Fig. 5) show that the basal unconformities of Pliocene-Quaternary foreland basin sediments are similar to that on the seismic line 1 .

The unconformity is angular over a wide area (50 km wide, $300 \mathrm{~km}$ long), suggesting regional erosion. The foreland basin sediments progressively onlap the unconformity towards the craton and the corresponding stratigraphic gap increases towards the craton. The largest stratigraphic gap occurs at the distal parts of the foreland basin where Quaternary sediments overlie the Lower Miocence strata, representing a time gap more than 10 million years. On the other hand, the foreland basin fills proximal to the Taiwan orogen exhibit conformable sequences from Late Miocene, Pliocene to the Quaternary in an ascending order.

The increase in stratigraphic gap reflects the progressively younger transgression of the Pliocene-Quaternary orogenic sediments from Taiwan onto the Chinese passive margin combined with progressively older units of Miocene subcropping towards the distal basin margin. The basal unconformity is characterized by: (1) large-scale $(>100 \mathrm{~km})$ progressive erosion into older strata toward the craton; (2) the great time scale of onlap over 10 million years; and (3) most of the sediments in the foreland basin is derived from the Taiwan orogen. These characteristics of the basal unconformity suggest that it can be interpreted as a flexural forebulge unconformity (Sinclair et al., 1991; Crampton and Allen, 1995) rather than a type 1 unconformity mainly due to sea level changes (Van Wagoner et al., 1987).

The forebulge associated with foreland basins is generally subjected to non-deposition or subaerial erosion, resulting in an erosional unconformity. Continued movement of thrust sheets in the evolution of a foreland basin would cause the forebulge migration across the craton and result in a regional erosional unconformity (Jacobi, 1981; Stockmal et al., 1986; Lash, 1988; Sinclair et al., 1991; Crampton and Allen, 1995). The peripheral forebulge unconformity is different from that caused by eustatic sea-level changes (Jacobi, 1981). Our study shows that the regional forebulge unconformity of Western Taiwan Foreland Basin is no exception to those associated with other foreland basins.

The location of flexural forebulges at the distal part of Western Taiwan Foreland Basin can be recognized from the associated unconformity. Seismic lines show that there exists a narrow zone of regionally uplifted Miocene passive margin sequences unconformably overlain by Pliocene-Quaternary foreland basin fills at the basin margin on the cratonic side. The present uplifted feature of the maximum relief on the basal unconformity could delineate the trend and approximate the position of the forebulge of the Western Taiwan Foreland Basin (Fig. 2b). 


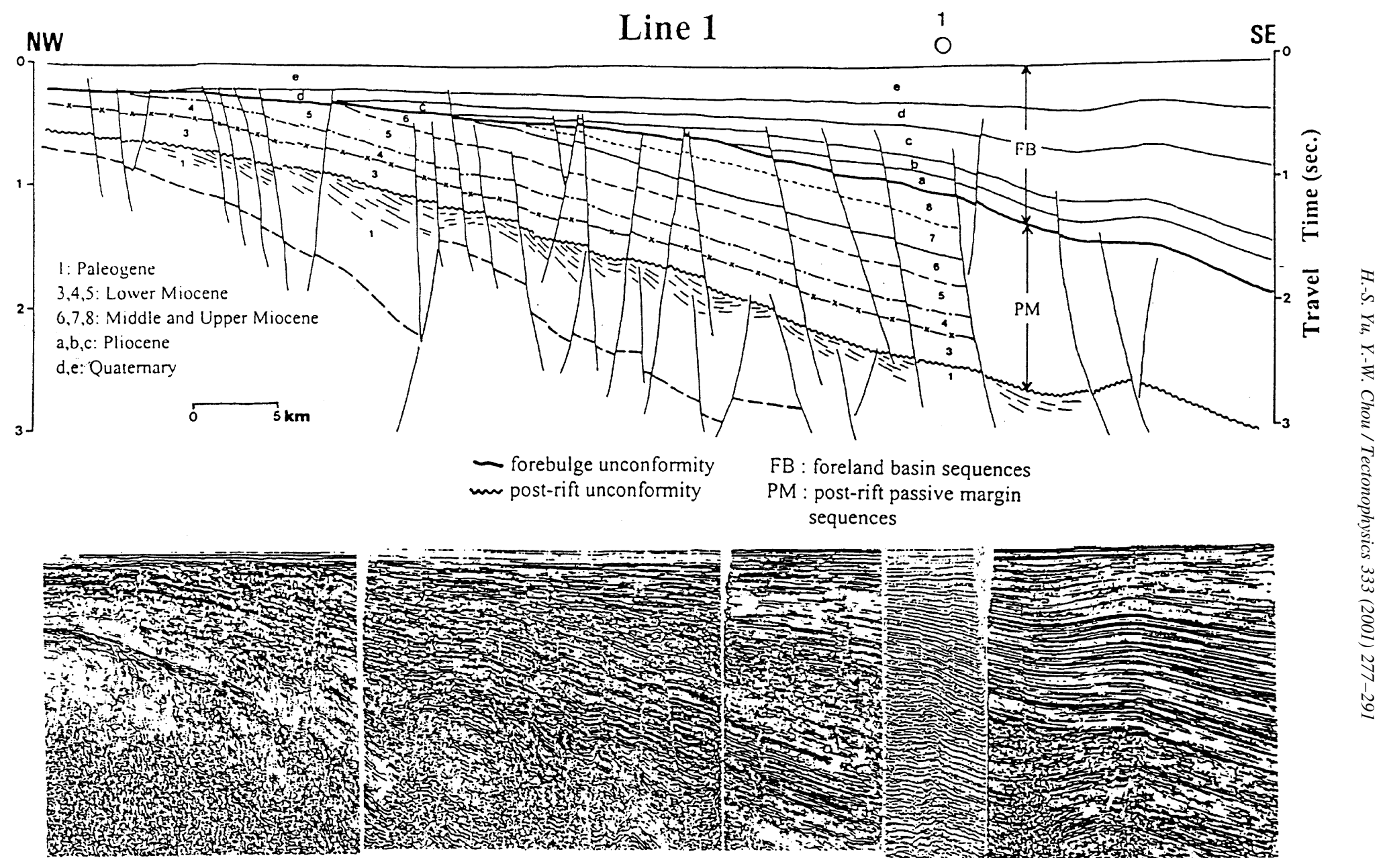

Fig. 3. Interpreted seismic line 1 showing an up-dipping basal unconformity separating the Pliocene-Quaternary foreland basin fills from the underlying passive margin strata. Foreland basin sediments progressively onlap the basal unconformity. Note that at the northwestern end of this section there is an erosional unconformity with Recent sediments overlying the Lower Miocene strata. Well No. 1 is marked by circle and is used to provide age calibration for the seismic interpretation. Locations of seismic line 1 and Well No. 1 refer to Fig. 2. 


\section{Line 2}

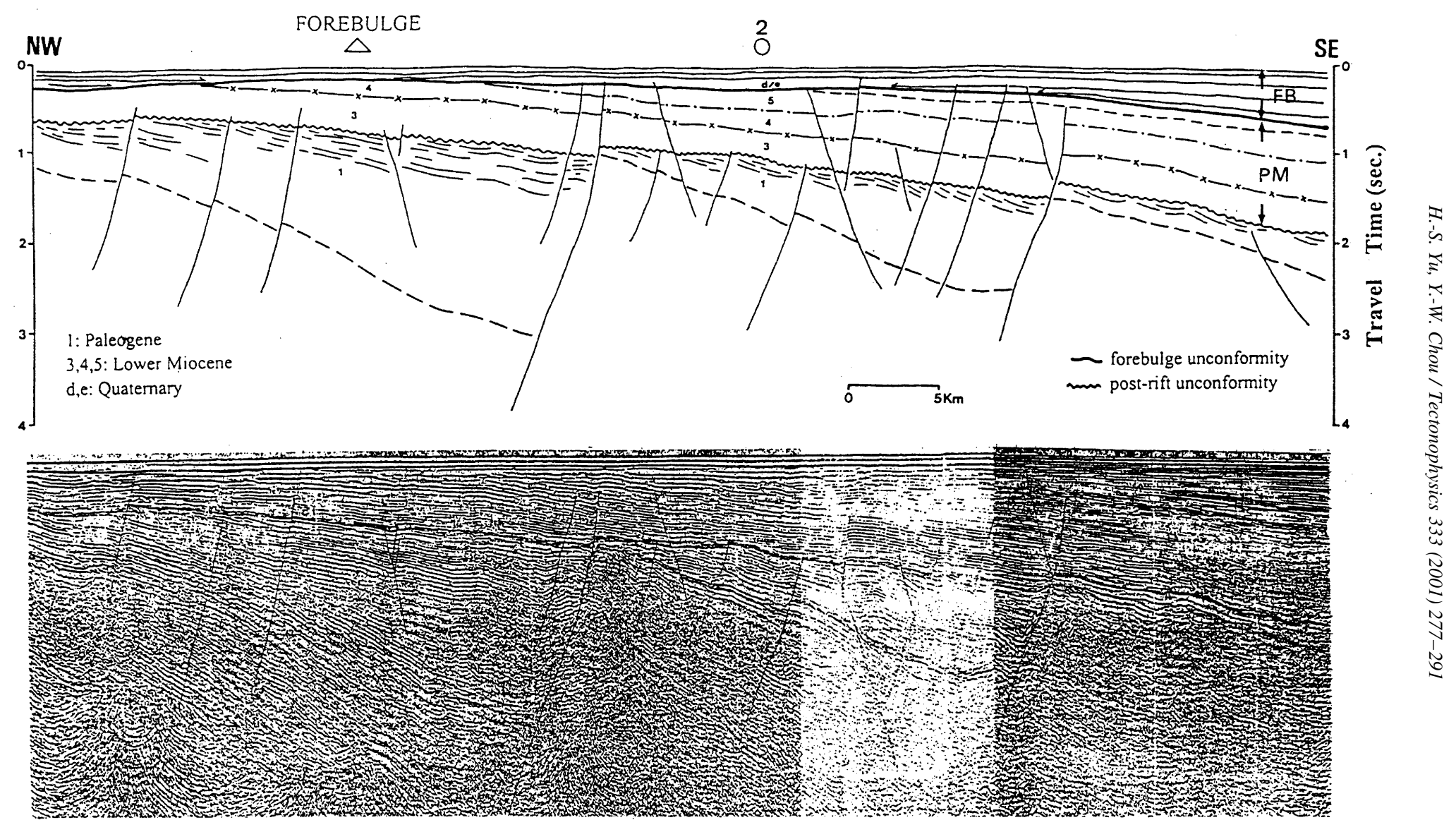

Fig. 4. The interpretation of seismic line 2 is similar to that of line 1 , except for the positive identification of a forebuge. $F B=$ foreland basin sequences, $P M=$ post-rift passive margin sequences. Locations of seismic line 2 and Well No. 2 refers to Fig. 2. 


\section{Line 5}

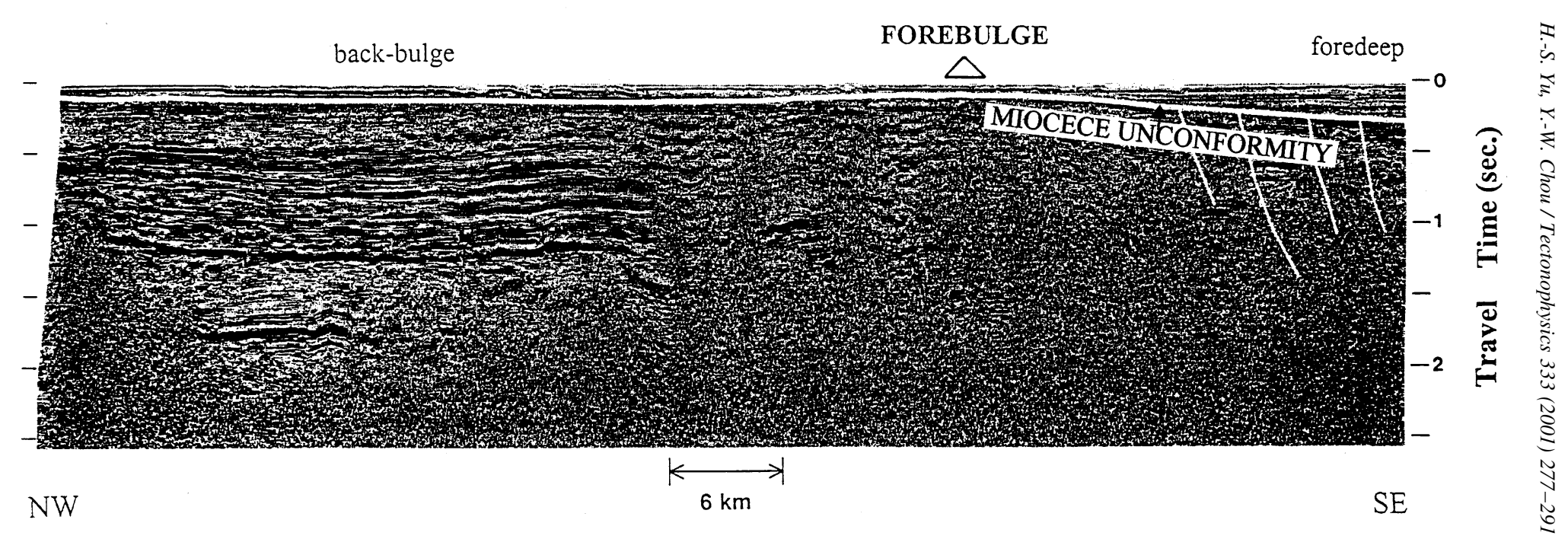

Fig. 5. Seismic line 5 shows the possible forebulge located at the highest place of the base of Pliocene foreland basin sediments. The shallow depression west of the forebulge is filled with sediments from China Mainland and is termed backbulge depozone. In contrast, the basin east of the forebulge is the foredeep receiving sediments from Taiwan. Location of seismic line 5 refers to Fig. 2. 
Seismic line 1 shows that there exists an uplifted feature at the basin margin and the crest of the uplifted bulge could be located around the middle of the Taiwan Strait, not far away from the northwest end of seismic line 1. As shown in Fig. 4, seismic line 2 shows that a positive feature of eroded Lower Miocene strata more than $5 \mathrm{~km}$ wide can be recognized where Quaternary sediments directly unconformably overlie the Miocene sequences with dual sediment sources both from Taiwan and China Mainland (Chou, 1976). It is noted that the PlioceneQuaternary sediments derived from Chinese Mainland are thinning towards the positively uplifted Miocene bulge (Fig. 5). The subtle morphologic/structural feature of Miocene strata can be interpreted as the flexural forebulge, the basin receiving sediments from Taiwan orogen as the foredeep and the shallow depression with sediments from Chinese Mainland as the backbulge depozone in terms of classification of foreland basin system (DeCelles and Giles, 1996).

Alternatively, the structural relief across the forebulge could be related to volcanic activity. The chaotic seismic facies underlying the possible forebulge could be interpreted as volcanic plug. The onlap pattern above the Miocene unconformity on the eastern part of seismic line 5 is not clearly seen as those on seismic lines 1 and 2 . Therefore, the possible forebulge shown on the seismic line 5 is debatable.

The aligned positive features of elevated Miocene strata located along the middle of Taiwan Strait runs approximately parallel to the strike of the deformation front of the Taiwan orogen (Fig. 2b). The maximum uplift occurs approximately $100 \mathrm{~km}$ from the deformation front of the Taiwan orogen and is generally less than $200 \mathrm{~m}$ high. The relative position of the uplifted feature with respect to that of the Taiwan orogen suggests that the Chinese margin was flexed downward in response to the tectonic loading of the westwards advancing thrust sheets of Taiwan. However, the shallow-water shelf on the Chinese margin was uplifted to form a forebulge. The width between the forebulge and the thrust sheets depends mainly on the flexural rigidity of the continental crust and the loading of the mountain belt (Beaumont, 1981; Speed and Sleep, 1982; Stockmal et al., 1986).

The identified forebugle of the Western Taiwan Foreland Basin is a subdued forebulge with low relief since it is buried by sediments shed from the Taiwan orogen which has reached a steady state (Covey, 1986) or an overfilled stage (Sinclair, 1997). The western Taiwan foredeep is unable to accommodate large volumes of orogenic sediments from Taiwan. Bypass sediments of the Taiwan orogen thus travel as far as the middle of Taiwan Strait and bury the forebulge.

\section{Evidence for flexural forebulge based on gravity anomalies}

An elongated narrow zone at the basin margin of the Western Taiwan Foreland Basin matches with positive Bouguer anomalies of about $30 \mathrm{mgal}$ (Hsu et al., 1998). In contrast, the adjacent foreland basin proximal to the Taiwan orogen is associated with negative gravity anomalies, reflecting mass deficiency caused by thick infill of much less dense sediment of the basin. The gravity anomaly profiles across the basin also agree with that of the flexure caused by the end-loading, which creates an asymmetrical foredeep bounded on the cratonic side by a flexural forebulge with a higher density than the adjacent foredeep. Therefore, the uplifted Miocene strata located in the middle of Taiwan Strait show many aspects of a flexural feature (Jacobi, 1981; Crampton and Allen, 1995; DeCelles and Giles, 1996), and hence, it can be interpreted as a present-day forebulge belonging to the Western Taiwan Foreland Basin.

\section{Evidence for flexural forebulge based on lateral facies changes}

Quaternary sands from Well No. 2 near the forebulge are well-to-moderately sorted but the equivalent sands from Well No. 1 and No. 3, located far away from the forebulge, are moderately-to-poorly sorted. Location of these wells is shown in Figs. $2 b$ and 6. Quaternary sediments from Well No. 2 contain abundant debris of coral reef. In contrast, fragments of carbonate rocks are not found from Quaternary sediments from Well No. 1 and No. 3. It appears that the forebulge region has been uplifted to become shallow marine shelf with high-energy regime, resulting in deposition of well-sorted sands. The middle of Taiwan Strait became the site of carbonate sedimentation when the supply of clastic sediments decreased. 


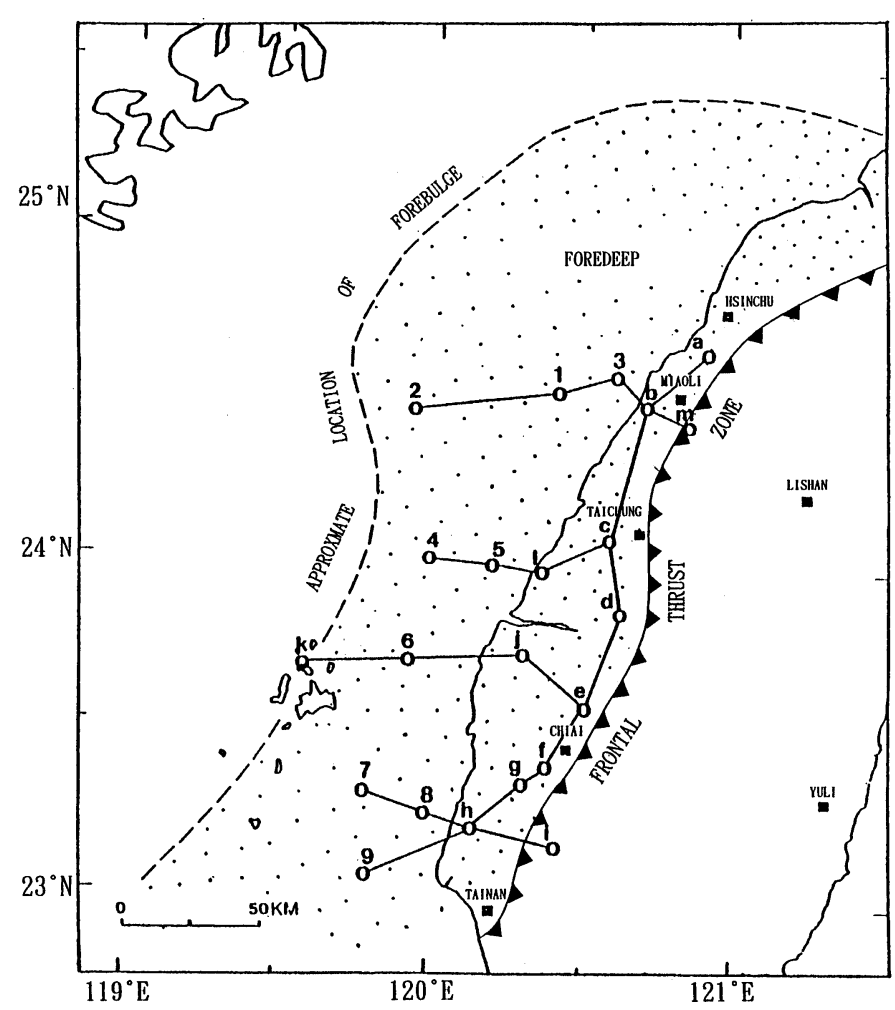

Fig. 6. The areal extent of the basal unconformity of the Western Taiwan Foreland Basin is between the forebulge along the middle of the Taiwan Strait and the frontal thrust zone of Taiwan. Four chronostratigraphic sections across the foredeep and one chronostratigraphic section along the tectonic strike are constructed by connecting wells to show the time and space distributions of the unconformity. Locations of twentytwo wells are marked by circles that are consistent with those marked in Figs. 2-4.

In the equivalent time intervals, the sites of Well No. 1 and No. 3 at the down dip side of the forebulge have not been flexed upward and belong to low-energy offshore depositional environments, producing poorly sorted sands. Being close to the deformation front of Taiwan the sites of Well No. 1 and No. 3 are dominated by silisiclastic sedimentation where much terrigenous supply from emergent thrust sheets was received, with the result of no carbonate deposits.

The variations of sedimentary features between these core samples from these three wells could be related to the flexural uplift effect on the sedimentation in the Western Taiwan Foreland Basin.

\section{Discussion}

The flexural forebulge unconformity of Western
Taiwan Foreland Basin extends from the frontal thrust zone to the middle of Taiwan Strait (Fig. 6). Using 22 wells onshore and offshore, we constructed four chronostratigraphic sections across the foreland basin and one chronostratigraphic section along the strike of front thrust zone to illustrate the variations of the stratigraphic pattern of the unconformity (Figs. 7 and 8).

The northernmost chronostratigraphic section near the city of Miaoli shows that the Pliocene sediments conformably overlying the Miocene passive sequences are confined to the coastal area in front of the thrust zone (Fig. 7). Conformable strata pass laterally westward into unconformable sequences in the eastern Taiwan Strait with small stratigraphic gap between the base of Pliocene foreland basin deposits and underlying Late Miocene passive margin strata. The unconformity gap then increases progressively westward with the largest chronostratigraphic 
MIAOLI SECTION

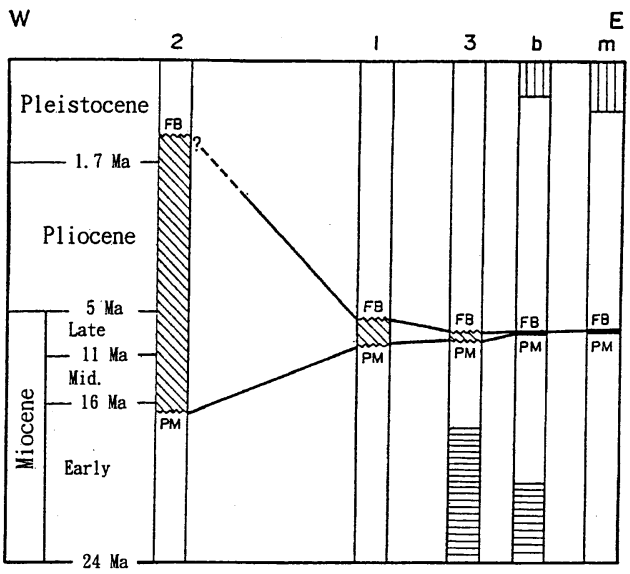

CHIAI SECTION

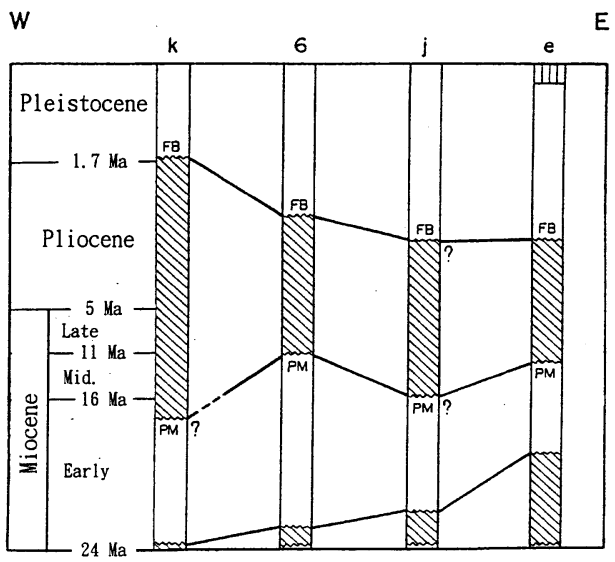

TAICHUNG SECTION

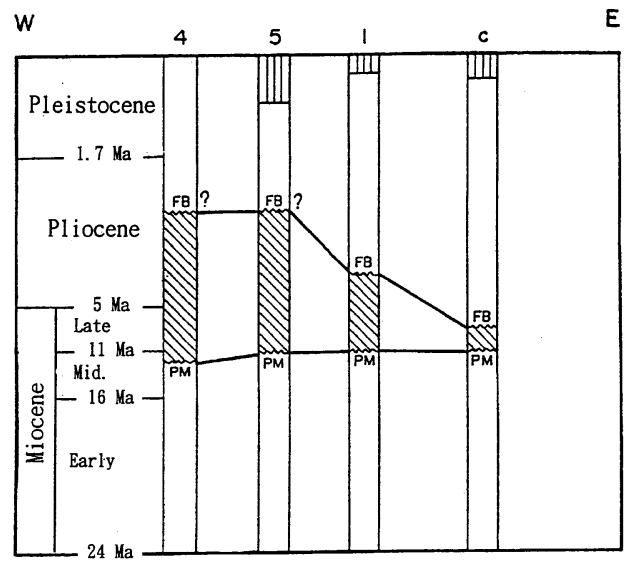

TAINAN SECTION

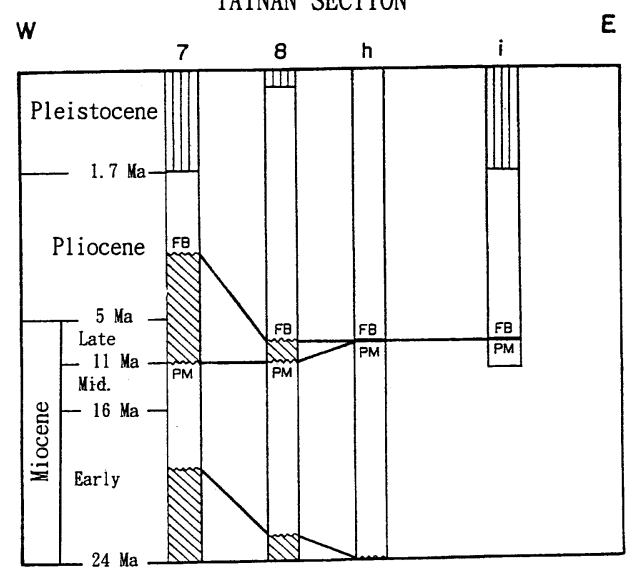

Fig. 7. Four chronostratigraphic sections across the foredeep reveal the changes in stratigraphic pattern from north to south in the foreland basin. Note that the unconformity gap separating foreland basin sediments from underlying passive margin sequences is progressively increasing towards the forebulge region. The eastern ends of the northernmost and southernmost sections near the frontal thrust zone are represented by conformity between the foreland basin sediments and the passive margin strata. Chronostratigraphic gap is marked by hatch lines. Vertical-ruled pattern is missing equivalent strata.

gap between the Pleistocene sediments and the underlying Upper Miocene strata at the middle of Taiwan Strait.

In central Taiwan, the chronostratigraphic section near the city of Taichung shows that the chronostratigraphic gap across the unconformity increases cratonward with the largest gap occurring near the middle of Taiwan Strait (Fig. 7). The small gap between Late and Middle Miocene deposits occurs in the frontal thrust zone and the large gap with Late Pliocene formation overlying Middle Miocene sandstones was encountered by Well No. 4 east of middle of Taiwan Strait.

Farther south, the chronostratigraphic section from Chiai to the Penghu Islands shows that the chronostratigraphic gap across the unconformity is relatively larger than that of the Taichung cross-section. The chronostratigraphic gap is found to be largest at Well $\mathrm{K}$ in the Penghu Islands where Middle and Late Miocene sequences and entire Pliocene strata are missing (Fig. 7). The southernmost chronostratigraphic section north of Tainan City shows a 


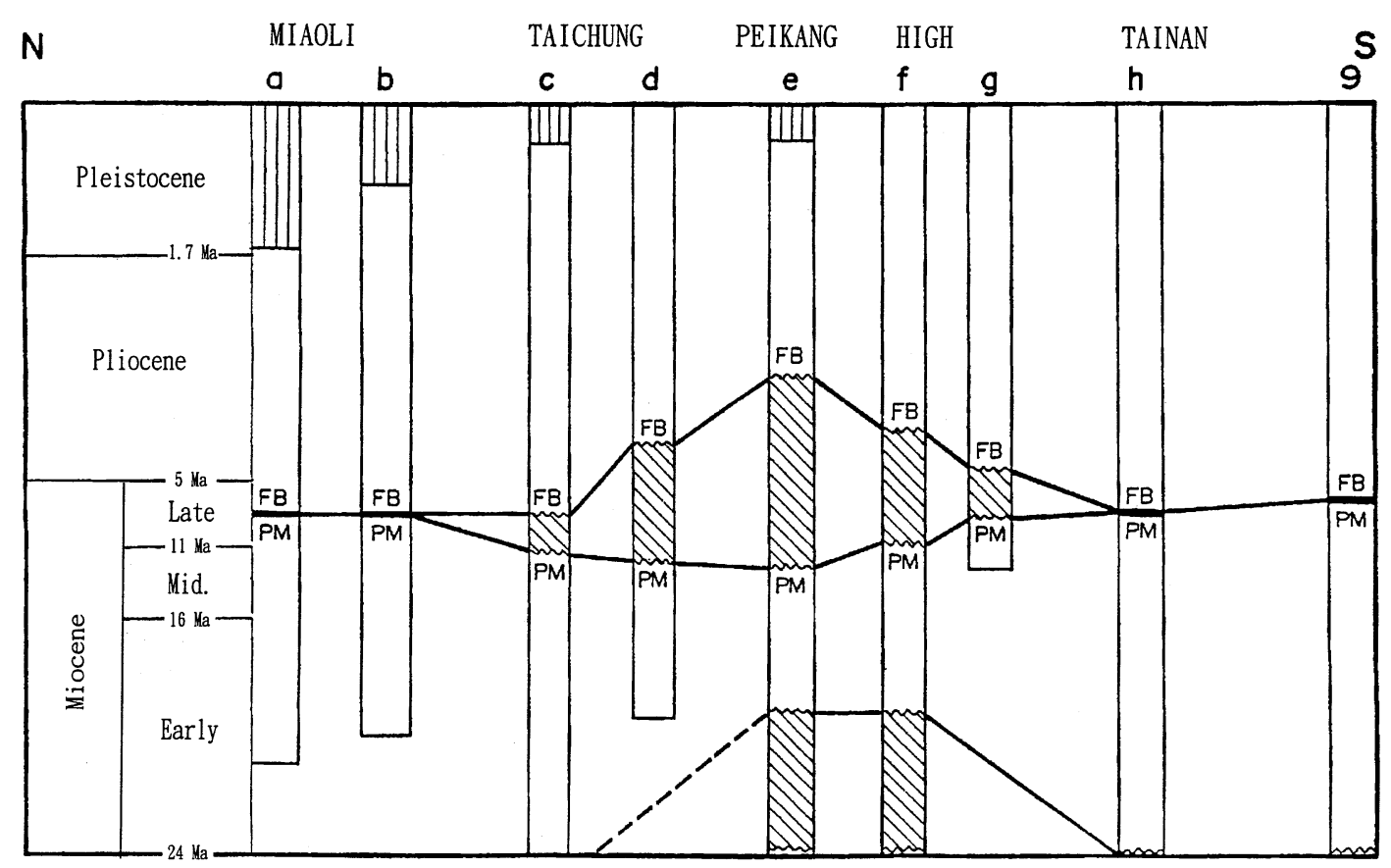

Fig. 8. The unconformity gap separating foreland basin sediments from underling passive margin sequences is not uniform along the strike of the frontal thrust zone. The foreland basin deposits are conformably on the passive margin sequences around the Miaoli areas in northwestern Taiwan. Chronostratigraphic gap associated with paleo-structural high adds extra component of time gap nearby the Peikang basement high. The sediments then change to the southwest laterally into conformity in the coastal and offshore areas. The variation of unconformity along tectonic strike is mainly controlled by the pre-deformation irregular morphology of the Chinese passive margin, e.g. the Mioali reentrant and the Peikang promontory in Late Miocene. Chronostratigraphic gap is marked by hatch lines. Vertical-ruled pattern is missing equivalent strata.

chronostratigraphic pattern similar to that of the northernmost cross-section of Miaoli. The foreland basin sediments overlying the unconformity change laterally, towards the Taiwan orogen, into conformity or disconformity of insignificant gap at the coastal plain and frontal thrust zone (Fig. 7).

Chronostratigraphic sections of Mioli, Taichung and Tainan can be regarded as records of the forebulge migration across the Chinese margin and the resultant basal unconformity with chronostratigraphic gaps increasing cratonward. However, the relatively large gap on the section from Chiai to Peikang is likely due to erosion or non-deposition associated with the paleo-structural high of Peikang. Still, the distribution of the basal unconformities in time and space (Fig. 7) may suggest a scenario of transition from the passive Chinese margin to the Western Taiwan Foreland Basin like in the model of Stockmal et al. (1986).

Probably during Late Miocene, the proto-orogen of
Taiwan was largely below sea level, loading the outer edge of the Chinese margin and producing a deep, narrow basin in which Late Miocene deep water sediments are conformably deposited on the slope-rise of the Chinese margin. On the other hand, the distal parts of the basin, the shelf region of the Chinese margin was flexed upward to become the region of flexural forebulge, which tended to be eroded, non-deposition or receiving little terrigenous supply (Step II of Stockmal et al., 1986). During Pliocene, the thrusts continue to move onto the Chinese margin and the flexural Taiwan forebulge synchronously migrated westwards. Uplift of shallow-water shelf region above sea level followed by submergence resulted in an erosional basal unconformity, which is characterized by progressive erosion into older strata toward the craton because of the cratonward migration of forebulge with time (Step III of Stockmal et al., 1986).

Consequently, the progressively younger PlioceneQuaternary orogenic sediments from Taiwan are 
onlapping the Chinese passive margin above the unconformity. The progressively older Miocene units below the unconformity are subcropping towards the forebulge, resulting in a chronostraitgraphic pattern with increasing gap towards the Chinese craton (Step IV of Stockmal et al., 1986). The present-day Western Taiwan Foreland Basin probably is in Step V characterized by low topography and old margin.

These four chronostratigraphic sections reveal changes in stratigraphic pattern from north to south. The unconformity gap separating foreland basin sediments from underlying passive margin sequences is not uniform along the strike of the frontal thrust zone. Two cross-sections located west of Taichung and Chiai in central-south Taiwan are marked by greater stratigraphic gap. Lash (1988) pointed out that some shelf unconformities due to flexing upward and subsequent erosion at distal parts of foreland basin vary along the tectonic strike. This variation is mainly controlled by the pre-deformation morphology of the passive margin.

Using 9 wells, we constructed a north-south trending chronostratigraphic section parallel to the frontal thrust zone to examine the changes across the unconformity in detail and to relate variations in stratigraphic gap to the pre-collision shape of the Chinese passive margin (Fig. 8).

Fig. 8 shows that the foreland basin deposits are conformable on the passive margin sequences around the Miaoli areas in northwestern Taiwan. The foreland basin sediments change laterally to the south into unconformity in the Taichung area where some Late Miocene strata are missing. The stratigraphic gap progressively increases southwards and reaches the maximum at the Chiai area (Well e) where the sequences from the base of Late Miocene to the top of Early Pliocene are eroded. The stratigraphic extent of the unconformity decreases to the south towards the Well $\mathrm{g}$ where the base of Pliocene and small parts of Late Miocene sediments are missing. The foreland basin sediments overlying the unconformity change to the southwest laterally into conformity in the coastal and offshore areas (Wells g and 9).

Variations in the distribution of chronostratigraphic unconformities along the strike of Taiwan orogen can be interpreted in terms of the irregular Chinese passive margin colliding with the westward advancing Luzon Arc. The Peikang basement high, in the areas west of Chiai (Fig. 2b), is assumed to have behaved as a continental promontory. Those parts of the continental margin north and south of the Peikang basement high are convex to the Chinese craton, the continental reentrants (Biq, 1992), here tentatively called Miaoli reentrant. The continent-arc collision in Taiwan is occurring obliquely from north to south (Suppe, 1981). The northeast-southwest trending Chinese passive margin makes an angle with the north-south trend of the Luzon Arc.

During early collision, the thrust terrane of proto Taiwan moved onto the Chinese margin of which the Peikang promontory has been emergent from Late Miocene to Late Pliocene as evidenced by missing strata of Late Miocene to Early Pliocene. The Peikang high was formed before Oligocene and the tectonic loading occurred much later. Thus, the chronostratigraphic gap in the Peikang area was mainly caused by paleo-structural morphology rather than by tectonic loading. In contrast, the adjacent Miaoli located in a structural-low received sediments as evidenced by a complete sequence of Late Miocene to Pliocene deposits. In the late stage of collision, with continued cratonward migration of the thrust terrane, the formerly exposed Peikang promontory and Miaoli reentrant subsided to form a foreland basin receiving younger sediments. However, the distal parts of the Chinese margin west of the Peikang promontory and Miaoli reentrant were flexed up in response to the tectonic loading and were subsequently subjected to erosion. Finally, the forebulge migrated to the middle of Taiwan Strait along with the accompanying foreland basin that migrated toward the Chinese craton, resulting in a westward onlap of sediments from the Taiwan orogen above the basal unconformity.

\section{Summary and conclusions}

We recognized a major unconformity separating the overlying sediments of foreland basin from the underlying passive margin strata and a flexural forebulge located at the distal part of the foreland basin. Flexural forebulges occur as a narrow zone of uplifted Miocene strata extending approximately parallel to the strike of the deformation front of Taiwan orogen. The Miocene bulge is generally $200 \mathrm{~m}$ high and is characterized by an unconformity where Quaternary 
sediments overlie eroded Miocene strata. Positive gravity anomalies are associated with the Miocene bulge, indicating higher density materials.

The regional unconformity at the base of the Pliocene-Quaternary foreland basin fills is an angular unconformity that extends over $100 \mathrm{~km}$ across the foreland basin, implying events of regional erosion. The characteristic geometry, stratigraphic gap increasing cratonward and large stratigraphic duration (up to 10 million years) suggest that the basal unconformity is a flexural forebulge unconformity rather than being due to sea level changes. The flexural forebulge and associated basal unconformity mark transition from shelf-slope deposition on a passive margin to deposition in a foreland basin associated with a convergent margin, reflecting the uplift and erosion of progressively cratonward migrating forebulge.

\section{Acknowledgements}

J.C. Chen, Institute of Oceanography, National Taiwan University and F.W. Huang, Chinese Petroleum Cooperation, Taiwan reviewed the manuscript. Constructive comments from Neil Lundberg, Florida State University are greatly appreciated. We thank the Chinese Petroleum Cooperation for giving permission for using and publishing the seismic and well data of this study. Critical reviews and constructive comments of O. Lacombe, Jean-Pierre Burg and an anonymous reviewer improved this manuscript greatly.

\section{References}

Biq, C., 1972. Dual-trench structures in the Taiwan-Luzon region. Geol. Soc. China Proc. 15, 65-75.

Biq, C., 1992. Another coastal range on Taiwan. Ti-Chih 12, 1-14 (in Chinese)

Biq, C., 1997. Taiwan. In: Moore, E.M., Fairbridge, R.W. (Eds.), Encyclopedia of European and Asian Regional Geology, pp. 711-717.

Beaumont, C., 1981. Foreland basins. Geophys. J. Res. Astron. Soc. 65, 291-329.

Bowin, C., Lu, R.S., Lee, C.S., Schouten, N., 1978. Plate convergence and accretion in Taiwan-Luzon region. Am. Assoc. Petrol. Geol. Bull. 62, 1645-1672.

Chai, B.H.T., 1972. Structure and tectonic evolution of Taiwan. Am. J. Sci. 272, 389-422.

Chi, W.R., Namson, J., Suppe, J., 1981. Stratigraphic record of plate interactions in the Coastal Range of eastern Taiwan. Geol. Soc. China Mem. 4, 155-194.

Chiang, C.S., 1998. The tectonic features of the Kaoping ShelfSlope region off southwestern Taiwan-wedge-top depozone. $\mathrm{PhD}$ thesis, National Taiwan University, $130 \mathrm{pp}$.

Chou, S.C., Teng, L.S., Chung, H.S., Shiao, T.W., 1994. Geohistory analysis of western Taiwan foreland basin: a preliminary study. Petrol. Geol. Taiwan 29, 289-323 (in Chinese).

Chou, J.T., 1976. Sedimentology and paleography of the Miocene clastic sequence in northern Taiwan, with emphasis on its sandstones. Petrol. Geol. Taiwan 13, 83-118.

Chou, Y.W., Yu, H.S., 1997. Structural expression of flexural extension in collisional Western Taiwan Foredeep. Annual Meeting of Geological Society of China, Tainan, Taiwan, Extented Abstract, pp. 372-375.

Chou, Y.W., Yu, H.S., 1998. Structural expression of flexural extension in collisional Western Taiwan Foredeep (submitted to Geol. Soc. Am. Bull. Special Issue, under revision).

Covey, M., 1984. Lithofacies analysis and basin reconstruction, Plio-Pleistocene western Taiwan foredeep. Petrol. Geol. Taiwan 20, 53-83.

Covey, M., 1986. The evolution of foreland basin to steady state: evidence from the western Taiwan foreland basin. In: Allen, P.A., Homewood, P. (Eds.), Foreland Basins. Int. Assoc. Sediment. Spec. Publ., 8, pp. 77-90.

Crampton, S.L., Allen, P.A., 1995. Recognition of forebulge unconformities associated with early stage foreland basin development: example from the North Alpine Foreland Basin. Am. Assoc. Petrol. Geol. Bull. 79, 1495-1514.

DeCelles, P.G., Giles, K.A., 1996. Foreland basin system. Basin Res. 8, 105-125.

Dickinson, W., 1974. Plate tectonics and sedimentation. In: Dickinson, W. (Ed.), Tectonics and Sedimentation. Spec. Publ. Soc. Econ. Paleont. Miner., pp. 1-27.

Fleming, P.B., Jordan, T.E., 1989. A synthetic stratigraphic model of foreland basin development. J. Geophys. Res. 94B, 3851-3866.

Ho, C.S., 1988. An Introduction to the Geology of Taiwan: Explanatory Text of the Geological Map of Taiwan, 2nd ed., Ministry of Economics Affairs, 192 pp.

Hsu, S.K., Liu, C.S., Shyu, C.T., Liu, S.Y., Sibuet, J.C., Lallemand, S., Wang, C.S., Reed, D., 1998. New gravity and magnetic anomaly maps in the Taiwan-Luzon region and their preliminary interpretation. TAO 9, 509-532.

Jacobi, R.D., 1981. Peripheral bulge - a causal mechanism for the Lower/Middle Ordovician unconformity along the western margin of the Northern Appalachians. Earth Planet. Sci. Lett. $56,245-251$.

Lash, G.G., 1988. Along-strike variations in foreland basin evolution: possible evidence for continental collision along an irregular margin. Basin Res. 1, 71-83.

Shiao, T.W., Teng, L.S., 1991. Flexural tectonics of western Taiwan foreland basin: a preliminary study. Proceedings of the Third Taiwan Symposium on Geophysics, pp. 437-446.

Sinclair, H.D., 1997. Tectonostratigraphic model for underfilled peripheral foreland basins: an Alpine perspective. GSA Bull. 109, 324-346.

Sinclair, H.D., Coakley, B.J., Allen, P.A., Watts, A.B., 1991. 
Simulation of foreland basin stratigraphy using a diffusion model of mountain belt uplift and erosion: an example from the central Alps, Switzerland. Tectonics 10, 599-620.

Speed, R.C., Sleep, N.H., 1982. Antler orogeny and foreland basin: a model. GSA Bull. 93, 815-828.

Stockmal, G.S., Beaumont, C., Boutilier, R., 1986. Geodynamic models of convergent margin tectonics: transition from rifted margin to overthrust belt and consequence of foreland basin development. Am. Assoc. Petrol. Geol. Bull. 70, 181-190.

Suppe, J., 1981. Mechanics of mountain building and metamorphism in Taiwan. Geol. Soc. China Mem. 4, 67-89.
Suppe, J., 1984. Kinematics of arc-continent collision, flipping of subduction, and back-arc spreading near Taiwan. Geol. Soc. China Mem. 6, 21-34.

Teng, L.S., 1987. Stratigraphic records of the Late Cenozoic Penglai orogeny of Taiwan. Acta Geol. Taiwan. 25, 205-224.

Van Wagoner, J.C., Mitchum, Jr. R.M., Posamentier, H.W., Vail, P.R., 1987. Seismic stratigraphy interpretation using sequence stratigraphy. Part 2: key definitions of sequence stratigraphy. In: Bally, A.W. (Ed.), Atlas of Seismic Stratigraphy. AAPG Studies in Geology, 27, pp. 11-14. 